than to the left, so that qualitatively it will be perceived as different from the same sound when heard directly in front. In the case of monaural hearing it is clear that the intensity of a sound can afford only the most ambiguous information. An appairent change in intensity in such a case may mean change of distance, change of direction, change of actual intensity or some combination of these alternatives. But the single ear is by no means so helpless as regards the detection of qualitative differences due to changes of direction. Our subject himself connected his capacity to localize sounds with this noticed change in quality. His results show that (although in every case he remained ignorant of his success or failure during the experimentation) he possessed to begin with a relatively accurate auditory orientation on the basis of these qualitative peculiarities of sounds due to their direction, and, furthermore, that after gaining a little familiarity with the sounds, his localizations became very accurate. Nor did he seem to find any serious difficulty in determining direction, when the absolute distance of the sounds was varied, nor yet when the absolute intensity was varied. Pure tones he could not localize for they undergo no qualitative modifications by change of direction. Intensity changes are the only ones of which they are susceptible. Slightly complex sounds he can localize fairly. Highly complex sounds, possessing component tones well inside the range of ready detection, he can localize extremely well, save in the region just opposite the deaf ear. The same statements hold for localizations above and below the equatorial plane, to which we have confined our description. The modifications met with outside this plane are all conformable to the fundamental theory of the dependence of the localizations upon qualitative differences in the sounds. The pinna, the meatus, the bones of the head, etc., all contribute to the production of these qualitative modifications.

James Rowland Angell.

The University of Chicago.

FOOD OF SEA LIONS.

The Colifornia State Board of Fish Commissione during the past two years has taken steps to kill off a very large number of sea lions on the California coast, on the ground that these animals are highly destructive to the salmon fishery. The president of the board, Mr. Alexander T. Vogelsang, claims that it is not the intention of the board to exterminate the sea lions, but merely to kill ' 10,000 of the 30,000 that now infest our harbor entrance and contiguous territory.' * The opinion of observers familiar with the sea lion rookeries is that the number of animals has been greatly exaggerated, and that long before Mr. Vogelsang has killed the contemplated 10,000 there would not be a living sea lion left on the whole coast. Already many have been killed and, unless public sentiment is aroused to check the movement, some of the most interesting rookeries of the State are in danger of depletion. The Fish Commissioners have employed men to shoot the sea lions, and are loud in their lamentations because the Government light-house reservations have not been thrown open to the slaughter.

The local fishermen, the State Fish Commission and others assert without qualification that the sea lions feed extensively on salmon, and the inference from their statements is that the animals subsist chiefly, if not entirely, on fish. A few years ago, when similar complaints were made against the fur seals, I took the trouble to examine the stomach contents of a large number of these animals, and found to my surprise

\footnotetext{
* In letter to Hon. Lyman J. Gage, Secretary of
} the Treasury, dated San Francisco, June 3, 1899.. 
that the great bulk of their food consisted of squids, hundreds of whose beaks and pens were found in the stomachs, while in only a few instances were any traces of fish discovered.

In 1899, a well-known naturalist, Prof. L. L. Dyche, of the University of Kansas, spent the months of June, July, August and September on the California coast, at a time when the sea lions were being slaughtered in the alleged interests of the fishermen. Professor Dyche became interested in the question of their food, and took the trouble to examine the stomachs of 25 sea lions, not one of which contained so much as a trace of fish. The region visited extends from Monterey Bay southward along the coast for about 25 miles.

Between June 25th and July 16th, there were washed ashore within three miles of Point Pinos, at the mouth of Monterey Bay, eight sea lions which had been shot, the fishermen said, because they were feeding on salmon. Professor Dyche examined the stomachs of all of these and has given me a detailed record of the contents of each. It would take too much space to print this in full. Suffice it to state that the remains of squids and cuttlefish (Octopus) were found in all, and that several were filled with large pieces of the giant squid. Notwithstanding the fact that at the same time and place salmon were being caught by fishermen, not a fish scale or bone was detected in any of the stomachs. Whenever possible Professor Dyche opened the stomachs in the presence of the fishermen, who invariably expressed the greatest surprise at the result. On July 20 th, Professor Dyche moved his headquarters southward and established a camp about twelve miles below Monterey Bay, between Point Carmel and the lighthouse, near which is an extensive rookery of sea lions. Between July 20th and August 16th, the stomachs of seventeen additional sea lions were ex- amined. Eight out of the seventeen were well filled with the flesh of the giant squid; two were gorged with large octopus, while the remaining seven contained pens and beaks of squids, the quantity varying from half a pint to about a quart.

Professor Dyche was told that there were no fish within two or three miles of the sea lion rookeries near his camp, as the sea lions had caught or driven them away. In the face of this statement, he himself caught a dozen rock cod one morning between shore and the seal rocks, and his boatman, George Carr, an old salmon fisherman, caught plenty of rock cod weighing from one to eight pounds each, within sixty feet of the flat rock where from one to 300 sea lions landed each day. The water close to these rocks, where the sea lions had lived for ages, proved to be the best fishing ground in the locality. Professor Dyche states further that he landed a number of times on the rocky islands where in places the excrement from the sea lions formed a layer a foot thick. He hunted through this for fish bones and scales, without being able to discover a single one. On the other hand, the tough pens from the backs of the squids were abundant.

Professor Dyche found the fishermen loud in their denunciation of the sea lions on account of their alleged destruction of salmon, but, although he was on the fishing grounds continuously for more than three months, the fishermen were unable to show him a single instance in which a sea lion had killed a salmon. He adds, "You can hardly imagine the surprised look on these fishermen's faces when they saw the great masses of squid meat roll out of the sea lions' stomachs when cut open."

The fact that sea lions in captivity will eat fish rather than starve has little bearing on the question, and the additional fact that salmon in nets are sometimes found bitten off or eaten is by itself no evidence 
at. all, particularly in places where either sharks or otters occur.

It is not claimed that sea lions in their native element never eat fish; at the same time the only actual evidence we have on the subject fails utterly to substantiate the allegations of the fishermen. On the contrary, all of the twenty-five stomachs of sea lions examined by Professor Dyche contained remains of squids or cuttle fishes, and not one contained so much as the scale or bone of a fish. And is it not significant that in former years, when sea lions were much more plentiful than now, salmon also were vastly more abundant? ' If the fishermen will look into their own habits and customs during the past twenty-five years, it is believed that the cause of decrease of the salmon will not be difficult to find, and this without charging the decrease to the inoffensive sea lions, whose rookeries constitute one of the greatest attractions to the visitor on the California coast.

\section{Hart Merriam.}

\section{SCIENTIFIC BOOKS.}

The Seri Indians. By W J McGeE. Extract from the Seventeenth Annual Report of the Bureau of American Ethnology. Washington, Government Printing Office, 1898 [1901]. Pp. 344 , with 62 plates, and 42 figures in the text. Seldom has one to chronicle the appearance of a work so thoroughly ' a contribution to human knowledge' as is this modestly titled essay. Brinton, in his 'American Race' (N. Y., 1891), styles the Seris 'a Yuma folk,' and consecrates a few lines to the enumeration of their not very prepossessing characteristics. Indeed, although these Indians came into contact with the whites in 1530-1540, they remained till towards the close of the nineteenth century perhaps the least studied of all the North American aborigines. The expeditions sent out in 1894 and 1895 by the Bureau of American Ethnology, under the efficient leadership of Dr. McGee, have resulted in the shedding of a flood of light upon one of the most interesting and remarkable groups of savages on the globe. After a brief introduction dealing with the salient features of the people, geographical nomenclature, etc., come sections on habitat (pp. 22-50), summary history (pp.51-122) ; tribal features-nomenclature, external relations, population (pp. 123-135) ; somatic charactersstature, color, etc., skull, skeleton, pedestrian habit, fleetness and endurance, absence of ' knife sense,' race sense, cheirization, alternation of states (pp. 136-163) ; demotic characters-symbolism and decoration, industries and industrial products, social organization, language ( $p p$. 164-344). Throughout these pages one is made aware of that noteworthy combination of keenness of perception and aptness of expression, that harmonious unity of the explorer and the recorder, which make the author's anthropological publications rank with the most sugges. tive and most stimulating scientific literature of the day.

The Seris (the word is Opata and means 'spry'), or, as they call themselves (by a name including fire and the, animal world) $K^{m} k \alpha a k$, 'our-great-mother-folk-here,' inhabit Tiburon Island (some 30 miles in length by from 12 to 20 in width) in the Gulf of California, and a limited adjacent area on the mainland of the Mexican State of Sonora. Two centuries ago they are said to have numbered several thousands, but almost uninterrupted warfare has reduced them to some 350 , of whom not more than 75 are adult males or warriors ; and, notwithstanding the fact that, under the renewed isolation of the last decade or two, they seem to have rallied their strength a little, or at least to have held their own, Dr. McGee holds out to us no other prospect than the 'early extinction of one of the most strongly marked and distinctive of aboriginal tribes.' In the historical summary the chief events in the contact of Caucasians and Seris, with their terrible results, in so far as the latter are concerned, are outlined, the concessions (now reported) of Seri territory to American speculators may be the beginning of the end. If so, the Seris will not have passed away without meeting an able and sympathetic chronicler. The importance of Dr. McGee's monograph for those engaged in the study of the phenomena of heredity and 